\title{
Do Exchange Rates Move in Line with Uncovered Interest Parity?
}

\section{Ronald Huisman, Ronald Mahieu and Arjen Mulder}

\begin{tabular}{|l|l|}
\hline \multicolumn{2}{|l|}{ ERIM REPORT SERIES RESEARCH IN MANAGEMENT } \\
\hline ERIM Report Series reference number & ERS-2007-012-F\&A \\
\hline Publication & January 2007 \\
\hline Number of pages & 7 \\
\hline Persistent paper URL & \\
\hline Email address corresponding author & rhuisman@rsm.nl \\
\hline Address & Erasmus Research Institute of Management (ERIM) \\
& RSM Erasmus University / Erasmus School of Economics \\
& Erasmus Universiteit Rotterdam \\
& P.O.Box 1738 \\
& 3000 DR Rotterdam, The Netherlands \\
& Phone: $\quad+31104081182$ \\
& Fax: $\quad+31104089640$ \\
& Email: info@erim.eur.nl \\
& Internet: $\quad$ www.erim.eur.nl \\
\hline
\end{tabular}

Bibliographic data and classifications of all the ERIM reports are also available on the ERIM website: www.erim.eur.nl 
ERASMUS RESEARCH INSTITUTE OF MANAGEMENT

\section{REPORT SERIES}

\section{RESEARCH IN MANAGEMENT}

\begin{tabular}{|c|c|}
\hline \multicolumn{2}{|c|}{ ABSTRACT AND KEYWORDS } \\
\hline Abstract & $\begin{array}{l}\text { According to uncovered interest rate Parity (UIP), the expected relative change in an exchange } \\
\text { rate is equal to the difference between interest rates between the two currencies. Empirically, } \\
\text { UIP is frequently rejected. In this paper, we examine whether exchange rates have at least any } \\
\text { tendency to move in the direction predicted by UIP and whether exchange rates tend to move } \\
\text { more in line with UIP in periods with large interest rate differentials. }\end{array}$ \\
\hline Free Keywords & Exchange rates, Uncovered interest rate parity, Logit models \\
\hline Availability & $\begin{array}{l}\text { The ERIM Report Series is distributed through the following platforms: } \\
\text { Academic Repository at Erasmus University (DEAR), DEAR ERIM Series Portal } \\
\text { Social Science Research Network (SSRN), SSRN ERIM Series Webpage } \\
\text { Research Papers in Economics (REPEC), REPEC ERIM Series Webpage }\end{array}$ \\
\hline Classifications & $\begin{array}{l}\text { The electronic versions of the papers in the ERIM report Series contain bibliographic metadata } \\
\text { by the following classification systems: } \\
\text { Library of Congress Classification, (LCC) } \underline{\text { LCC Webpage }} \\
\text { Journal of Economic Literature, (JEL), JEL Webpage } \\
\text { ACM Computing Classification System CCS Webpage } \\
\text { Inspec Classification scheme (ICS), ICS Webpage }\end{array}$ \\
\hline
\end{tabular}




\title{
Do EXCHANGE RATES MOVE IN LINE WITH UNCOVERED INTEREST PARITY?
}

\author{
Ronald Huisman $^{\mathrm{a}, \mathrm{c}}$, Ronald Mahieu ${ }^{\mathrm{a}, \mathrm{b}, \mathrm{c}}$, and Arjen Mulder ${ }^{\mathrm{a}}$ \\ ${ }^{a}$ RSM / Erasmus University \\ ${ }^{\mathrm{b}}$ Network for Studies on Pensions, Aging and Retirement (Netspar) \\ ${ }^{\mathrm{c}}$ Risktec Currency Management
}

January 2007

\begin{abstract}
According to uncovered interest rate Parity (UIP), the expected relative change in an exchange rate is equal to the difference between interest rates between the two currencies. Empirically, UIP is frequently rejected. In this paper, we examine whether exchange rates have at least any tendency to move in the direction predicted by UIP and whether exchange rates tend to move more in line with UIP in periods with large interest rate differentials.
\end{abstract}

Key words: Exchange rates, uncovered interest rate parity, logit models JEL classification: F31

Corresponding author: Ronald Huisman, RSM / Erasmus University, P.O. Box 1738, 3000 DR, Rotterdam, Netherlands, tel. +31 1040 82790, fax: +31 1040 89017. The respective email addresses are rhuisman@rsm.nl, rmahieu@rsm.nl, and amulder@rsm.nl. 


\section{Introduction}

The interest parity is the identity that relates interest rates to exchange rates. Uncovered interest parity (UIP) states that the expected percent change in the exchange rate is equal to the difference in interest rates between the currencies embedded in the exchange rate. According to UIP, an investor who borrows in a low interest rate country and puts her money on a bank account in a high interest country will not yield a persistent return on this investment, as the expected exchange rate movement will exactly offset her potential gains from the interest differential.

Empirically, the hypothesis for UIP to hold has frequently been rejected. Most tests are based on the regression framework by Hansen and Hodrick (1980) and Fama (1984): the future realized exchange rate returns are regressed on the current interest rate differential. If UIP holds, the coefficient on the interest differential should be equal to one. However, these tests typically results in a coefficient that is negative and often even significantly so. Subsequently, many have examined the empirical failure of UIP and proposed potential explanations. See Sarno (2005) and Lothian and Wu (2003) for recent overviews.

In this paper, we acknowledge that UIP does not hold perfectly. However, we hypothesize that exchange rates have a tendency to move in line with the UIP implied exchange rate. From this perspective, our study extends Wu and Zhang (1996) who perform non-parametric tests to examine whether exchange rates more frequently move in line with UIP or not. Instead of their non-parametric tests, we use a logit framework to examine the UIP tendency. This framework makes it possible to assess whether UIP tendeny can be explained by additional factors. The additional factor that we examine is the squared interest rate differential as suggested by Flood and Taylor (1996) and Huisman and Mahieu (2006) as they show that it is more likely that UIP holds in periods with high interest rate differentials. 


\section{The Logit model}

Our model starts from the Hansen and Hodrick (1980) and Fama (1984) regressions. Define $s_{t}$ as the logarithm of the exchange rate, measured as the U.S. Dollar (USD) price of one unit of foreign currency. Let $i_{t, k}$ be the USD interest rate observed at time $t$ for maturity date $t+k$ and let $\mathrm{i}_{t, k}{ }^{*}$ be the equivalent interest rate in the foreign country. The UIP regression can then be stated as

$$
\text { 1) } s_{t+k}-s_{t}=\alpha+\beta\left(i_{t, k}-i_{t, k}^{*}\right)+\varepsilon_{t, k} \text {. }
$$

Typically, $k$ is set to 1 in empirical work circumventing the issue of overlapping data ${ }^{1}$.

In order to examine UIP tendency, we propose to use a Logit model. To built the model, we define a binary variable $y_{t, k}$ that takes the value 1 if the exchange rate change between times $t$ and $t+k, s_{t+k}-s_{t}$, has the same sign as the current interest rate differential $i_{t, k}-i_{t, k}^{*}$ and 0 otherwise. Thus, if $y_{t, k}$, the exchange rate has moved in line with UIP. Note that this setup provides a weaker test of UIP as we do not impose that the exchange rate change exactly equals the size of the interest rate differential.

To formulate the Logit model, we define the latent variable $z_{t}$ such that $y_{t, k}=1$ if $z_{t}>0$ and $y_{t, k}=0$ if $z_{t} \leq 0$. We then model the latent variable $z_{t}$ linearly by using a set of $m$ explanatory variables $\boldsymbol{X}_{t}=\left\{x_{1 t}, \ldots, x_{m t}\right\}$, such that we obtain the following linear model

$$
\text { 2) } z_{t}=\boldsymbol{X}_{t} \boldsymbol{\beta}+u_{t}
$$

We estimate the parameters in the vector $\beta$ from this model using the Logit specification for the cumulative distribution of the errors $u_{t}$.

\footnotetext{
${ }^{1}$ Chinn and Meredith (2004) show that UIP cannot be rejected when the horizon $k$ is 5 years.
} 
We analyze two sets of explanatory variables $\boldsymbol{X}_{t}$. Initially, $\boldsymbol{X}_{t}$ only consists of a constant term to examine whether we exchange rates tend to move, on average, more in line with UIP or not. A positive value of the constant term implies that the exchange rate moves in line with UIP more often than moving in the opposite direction.

In the second case, we include a nonlinear transformation of the interest rate differential in the traditional regression (1), motivated by Bansal (1997). We are particularly interested in testing the claim of among others Flood and Taylor (1996), Huisman et al. (1998), and Huisman and Mahieu (2006), who find evidence for UIP in periods with large interest differentials. To do so, we propose the squared interest differential as the additional explanatory variable. If the above claim holds, there should be a stronger tendency to UIP in large interest differential periods and the coefficient for $\left(i_{t, k}-i_{t, k}^{*}\right)^{2}$, should be positive.

\section{Data}

We collected data for the following exchange rates against the U.S. dollar (USD) from the Datastream databases: Australian dollar (AUD), Canadian dollar (CAD), Swiss franc (CHF), Euro (EUR), British pound sterling (GBP), Japanese yen (JPY), Norwegian Krone (NOK), and Swedish Krona (SEK). For all these currencies we collected 3-month eurocurrency interest rates from Datastream, if available. For Australia, Norway and Sweden, we chose an interbank rate as the available eurocurrency rates do not cover the complete sample. For the Euro, we took the German eurocurrency rates prior to 1999. The sample runs from January 8, 1992 until May 16, 2006. All data is collected on a weekly frequency, giving us 749 observations in total.

\section{Results}

Table 1 contains the parameter estimates of both models. For each exchange rate, the parameter estimates for the first model are in the first row and the estimates for the second model are in the second row. The estimate for the constant term alpha for AUD in the first model equals -0.37 and is significantly different from zero. Interestingly, the AUD tends to move away from UIP more often than it moves in line. This also holds for 
JPY and NOK. Only EUR and SEK have positive and significant estimates. None of the other estimates are significant. Consistent with previous studies, we find weak evidence for UIP. Only EUR and SEK have the tendency to move in line with UIP; others do not and some even move more often in the opposite direction.

--- Insert Table 1 here ---

In the second model, we include the squared interest differential to examine whether UIP holds better in periods with large interest differentials. For each exchange rate, the estimates are in the second row. For the AUD, the estimate for the constant term is -0.29 and is significant and the estimate for the squared interest differential equals - 0.02 (not significant). Estimates for the latter are not significant for the CAD and GBP as well. However, an interesting result shows up for the CHF and the JPY. In both cases, the estimates for the constant term become positive, suggesting more than average movement in line with UIP, but the estimates for the squared interest differentials are significantly negative. For these exchange rates, it holds that the exchange rate moves less in line with UIP in periods with large interest differentials than in other periods. Interestingly, these currencies have on average low interest levels compared with the U.S. as can be seen from the fourth column in the tabel. Apparently, the large interest rate differentials attracts investors and triggers the demand for the U.S. Dollars as investors convert their borrowed Yens in U.S. Dollars to invest them in the U.S. The same holds for the Euro, although the interest rate differential has been slightly smaller than zero on average. The opposite result holds for the NOK and SEK. These exchange rates move more in line with UIP in periods with large interest differentials than in normal periods. In addition, their interest rates differentials are positive on average.

\section{Conclusions}

In this paper, we examined whether exchange rates tend to move in line with Uncovered Interest Rate Parity. Our results corroborate with earlier studies in that it is difficult to find evidence for UIP to hold as we find that most exchange rates even tend to move in the opposite direction. For currencies that have low interest rates levels relative to the 
U.S. (such as Japan), tend to move in line with UIP in normal periods, but in the opposite direction in periods in which the interest differential is large.

\section{References}

Bansal, R., 1997, An Exploration of the Forward Premium Puzzle in Currency Markets, Review of Financial Studies, 10, 369-403.

Chinn, M.D. and G. Meredith, 2004, Monetary Policy and Long Horizon Uncovered Interest Parity, IMF Staff Papers, 51 (3), 409-430.

Fama, E.F., 1984, Forward and Spot Exchange Rates, Journal of Monetary Economics, 14, 319-338.

Flood, R.P. and M.P. Taylor, 1996, Exchange Rate Economics: What's Wrong with the Conventional Macro Approach, In: J.A. Frankel, G. Galli and A. Giovannini (Eds.), The Microstructure of Foreign Exchange Markets, NBER, 261-332.

Hansen, L.P. and R.J. Hodrick, 1980, Forward Exchange Rates as Optimal Predictors of Future Spot Prices: An Econometric Analysis, Journal of Political Economy, 88, 829853.

Huisman, R., C.G. Koedijk, C. Kool and F. Nissen, 1998, Extreme Support for Uncovered Interest Parity, Journal of International Money and Finance, 17, 211-228.

Huisman, R. and R. Mahieu, 2006, Switching between Uncovered Interest Parity and a Random Walk, RSM / Erasmus University Working Paper.

Lothian, J.R. and L. Wu, 2003, Uncovered Interest Rate Parity over the Past Two Decades, Fordham University Working Paper.

Sarno, L., 2005, Viewpoint: Towards a Solution to the Puzzles in Exchange Rate Economics: Where Do We Stand?, Canadian Journal of Economics, 38 (3), 673-708.

Wu, Y. and H. Zhang, 1996, Assymetry in Forward Exchange Rate Bias, Economic Letters, 50, 407-411. 


\section{Appendix}

Table 1. Parameter estimates of model (1) and average interest rate differentials (IRD) for different exchange rates denoted against the U.S. Dollar.

\begin{tabular}{|c|c|c|c|}
\hline & $\alpha$ & $\beta$ & IRD \\
\hline \multirow[t]{2}{*}{ AUD } & $-0.37(0.08)$ & & \multirow{2}{*}{1.50 (1.48) } \\
\hline & $-0.29(0.10)$ & $-0.02(0.02)$ & \\
\hline \multirow[t]{2}{*}{ CAD } & $-0.09(0.07)$ & & \multirow{2}{*}{$0.30(1.36)$} \\
\hline & $-0.11(0.09)$ & $0.01(0.03)$ & \\
\hline \multirow[t]{2}{*}{ CHF } & $-0.10(0.07)$ & & \multirow{2}{*}{$-1.71(2.33)$} \\
\hline & $0.43(0.12)$ & $-0.07(0.01)$ & \\
\hline \multirow[t]{2}{*}{ EUR } & $0.63(0.08)$ & & \multirow{2}{*}{$-0.06(2.45)$} \\
\hline & $-0.83(0.10)$ & $-0.03(0.01)$ & \\
\hline \multirow[t]{2}{*}{ GBP } & $-0.03(0.07)$ & & \multirow{2}{*}{1.63 (1.59) } \\
\hline & $-0.05(0.08)$ & $0.00(0.01)$ & \\
\hline \multirow[t]{2}{*}{ JPY } & $-0.30(0.07)$ & & \multirow{2}{*}{$-3.25(2.10)$} \\
\hline & $0.07(0.11)$ & $-0.03(0.01)$ & \\
\hline \multirow[t]{2}{*}{ NOK } & $-0.22(0.07)$ & & \multirow{2}{*}{$1.41(3.05)$} \\
\hline & $-0.31(0.08)$ & $0.01(0.00)$ & \\
\hline \multirow[t]{2}{*}{ SEK } & $0.78(0.08)$ & & \multirow{2}{*}{1.28 (3.47) } \\
\hline & $-1.08(0.09)$ & $0.02(0.00)$ & \\
\hline
\end{tabular}

Robust pseudo-ML standard errors using Hubert/White procedure are between parentheses. For the average interest differentials, we provide standard deviations of the interest differentials in parenthesis. 


\section{Publications in the Report Series Research ${ }^{*}$ in Management}

\section{ERIM Research Program: "Finance and Accounting"}

2007

Revisiting Uncovered Interest Rate Parity: Switching Between UIP and the Random Walk Ronald Huisman and Ronald Mahieu ERS-2007-001-F\&A

http://hdl.handle.net/1765/8288

Hourly Electricity Prices in Day-Ahead Markets

Ronald Huisman, Christian Huurman and Ronald Mahieu

ERS-2007-002-F\&A

http://hdl.handle.net/1765/8289

Do Exchange Rates Move in Line with Uncovered Interest Parity?

Ronald Huisman, Ronald Mahieu and Arjen Mulder

ERS-2007-012-F\&A

Hedging Exposure to Electricity Price Risk in a Value at Risk Framework

Ronald Huisman, Ronald Mahieu and Felix Schlichter

ERS-2007-013-F\&A

* A complete overview of the ERIM Report Series Research in Management: https://ep.eur.nl/handle/1765/1

ERIM Research Programs:

LIS Business Processes, Logistics and Information Systems

ORG Organizing for Performance

MKT Marketing

F\&A Finance and Accounting

STR Strategy and Entrepreneurship 